\title{
ILLUSTRATIONS
}

Lafayette

Plaster bust by Jean-Antoine Houdon, ca. 1785. Boston

frontispiece Athenaeum.

"An East Prospect of the City of Philadelphia; taken by George

Heap from the Jersey Shore, made under the Direction of

Nicholas Scull Surveyor General of the Province of

Pennsylvania"

Etching printed by T. Jeffereys, near Charing Cross, London, [1768]. Reproduced from the collection of the Library of Congress.

The Chevalier Anne-César de La Luzerne

Oil by Charles Willson Peale, ca. 1781-1782. Independence National Historical Park Collection.

Lafayette's Proclamation to the Canadians

Printed broadside, 1780 . Nourse Family Papers (349o-a), Manuscripts Department, University of Virginia Library.

Jean-Baptiste-Donatien de Vimeur, Comte de Rochambeau

Oil by Charles Willson Peale, 1782. Independence National Historical Park Collection.

A view of the City of New York from Long Island

Ink and watercolor drawing by Montresor?, ca. 1776-1778. Reproduced from the collection of the Library of Congress.

"Map of the town, roadstead, and environs of Newport, with the French army encampment nearby in 1780 , its emplacements, and the fleet anchorage" Map by Henri Crublier d'Opterre, 1780. From the Collection of Paul Mellon, Upperville, Virginia.

François-Jean, Marquis de Chastellux

Oil by Charles Willson Peale, 1782 . Independence National Historical Park Collection. 
Engraving by Clément Bervic, 178o. Fogg Art Museum, Harvard University. Bequest of Francis Calley Gray.

"Return" of Lafayette's light division, August 10, 1780

Lilly Library, Indiana University.

Benedict Arnold

Engraving by Bénoit-Louis Prévost from a portrait by PierreEugène Du Simitière, 1781. Courtesy of The New-York Historical Society, New York City.

John André

Pen-and-ink self-portrait on the eve of execution. Yale University 183 Art Gallery. Gift of Ebenezar Baldwin, B.A., 1808.

Lafayette's encoded letter to Vergennes, October 4, 1780 Archives du Ministère des Affaires Etrangères, Paris.

Map of the British and Hessian encampments on Staten Island Ink and watercolor map by Michel Capitaine du Chesnoy?, ca. 1780 ? Courtesy of the Service historique de l'Armée, Vincennes (L-1-D-16o).

Henry Lee

Oil by Charles Willson Peale, 1782 . Independence National His208 torical Park Collection.

\section{Nathanael Greene}

Oil by Charles Willson Peale, 1783. Independence National Historical Park Collection.

Lafayette to John Mercereau, November 8, 1780

Rhode Island Historical Society.

Alexander Hamilton

Miniature by Charles Willson Peale, ca. 1777. Courtesy of

Nathaniel Burt. Photo courtesy of the Frick Art Reference Library. Location of original unknown.

Chevalier Jean-Baptiste de Gouvion

Oil by anonymous artist, date unknown. Courtesy of Bernard Cordier, Paris.

Joseph Reed

Oil by Charles Willson Peale, 1783 . Independence National Historical Park Collection.

Arthur St. Clair

Oil by Charles Willson Peale, 1780. The Metropolitan Museum of Art, Morris K. Jesup Fund, 1932. 
Oil by Rembrandt Peale, date unknown. National Gallery of Art, Washington; Andrew Mellon Collection.

John Laurens

Miniature by Charles Willson Peale, 1780. Gibbes Art Gallery, Charleston. By permission of John Laurens.

Thomas Jefferson

Bust of Seravezza marble by Jean-Antoine Houdon, 1789. Courtesy Museum of Fine Arts, Boston. George Nixon Black Fund.

Baron Friedrich Wilhelm von Steuben

Oil by Ralph Earl, ca. 1786. New York State Historical Association, Cooperstown.

Timothy Pickering

Oil by Charles Willson Peale, 1792. Independence National Historical Park Collection.

View of the French army and squadron at Newport, including the Romulus

Pen-and-watercolor drawing by anonymous artist, ca. March-April 1781 . Historical Society of Pennsylvania. Prints and Drawings, Bc $68 \mathrm{R}_{34} 6$.

Mordecai Gist

Oil supposedly by Charles Willson Peale, ca. 1774. Courtesy of a private collector.

Diagrams of the Battle of Cape Henry, March 16, 1781

Service Historique de l'Armée, Etat-Major de l'Armée, Vincennes. Photo courtesy of W. J. Barron. 